\title{
Grasses and legumes as cover crop in no-tillage system in northeastern Pará Brazil
}

\author{
Renato Alves TEIXEIRA ${ }^{1 *}$, Tatiana Gazel SOARES ${ }^{2}$, Antonio Rodrigues FERNANDES ${ }^{3}$, \\ Anderson Martins de Souza BRAZ ${ }^{4}$ \\ 1 Universidade Federal Rural da Amazônia - Programa de Pós Graduação em Agronomia, Av. Presidente Tancredo Neves № 2501, Bairro Montese, Cep 66.077-091, Belém - PA, Brasil. \\ ${ }^{2}$ Universidade Federal Rural da Amazônia - Programa de Pós Graduação em Ciências Agrárias, Av. Presidente Tancredo Neves № 2501, Bairro Montese, Cep 66.077-091, Belém - PA, Brasil. \\ 3 Universidade Federal Rural da Amazônia - Instituto de Ciências Agrárias Av. Presidente Tancredo Neves № 2501, Bairro Montese, Cep 66.077-091, Belém - PA, Brasil. \\ ${ }^{4}$ Universidade de São Paulo, Escola Superior de Agricultura Luiz de Queiroz- Programa de Pós graduação em Solos e nutrição de plantas, Av. Pádua Dias, №11, Bairro São Dimas, \\ Cep 13.418-000, Piracicaba - SP, Brasil. \\ Corresponding author: alves.agro@gmail.com
}

\section{ABSTRACT}

Studies to select one or more species of coverage plants adapted to Amazonian soil and climate conditions of the Amazon are a promising strategy for the improvement of environmental quality, establishing no-till agricultural systems, and thereby reducing the impacts of monoculture farming. The aim of this study was to assess the persistence time, half-life time, macronutrient content and accumulation, and C:N ratio of straw coverage in a Ultisol in northeastern Pará. Experimental design was randomized blocks with five treatments and five replicates. Plants were harvested after 105 days, growth and biomass production was quantified. After 84 days, soil coverage was 97, 85, 52, 50, and 15\% for signalgrass (Brachiaria brizantha) (syn. Urochloa), dense crowngrass (Panicum purpurascens), jack bean (Canavalia ensiformes), pearl millet (Pennisetum americanum) and sunn hemp (Crotalaria juncea,), respectively. Signalgrass yielded the greatest dry matter production $\left(9,696 \mathrm{~kg} \mathrm{ha}^{-1}\right)$. It also had high C:N ratio (38.4), long half-life (86.5 days) and a high persistence in the field. Jack bean also showed high dry matter production $\left(8,950 \mathrm{~kg} \mathrm{ha}^{-1}\right)$, but it had low C:N ratio (17.4) and lower half-life time (39 days) than the grasses. These attributes indicate that signalgrass and jack bean have a high potential for use as cover plants in no-till agricultural systems in the State of Pará.

KEYWORDS: Half-life, persistence of plant biomass, recycling nutrients, C / $\mathrm{N}$ ratio

\section{Gramíneas e leguminosas como plantas de cobertura para o sistema de plantio direto no nordeste do estado do Pará}

\section{RESUMO}

Estudos que visem à seleção de espécies, ou de grupos de espécies de plantas de cobertura do solo adaptadas as condições edafoclimáticas amazônicas parece ser uma estratégia viável para a melhoria da qualidade ambiental por propiciar o estabelecimento do SPD atenuando problemas relacionados ao monocultivo. O objetivo foi avaliar o comportamento de plantas de cobertura, no Nordeste paraense, quanto a persistência, tempo de meia vida, teor e acúmulo de macronutrientes e relação C/N na palhada, em Argissolo Vermelho Amarelo. O delineamento experimental foi em blocos ao acaso, com cinco tratamentos e cinco repetiçóes. As plantas foram cultivadas a partir do mês de julho e cortadas aos 105 dias de cultivo e então foi feita a avaliação da produçáo. Ao final dos 84 dias a percentagem de cobertura do solo correspondeu a 97, 85, 52, 50 e 15\%, para a braquiária (Brachiaria brizantha) (syn. Urochloa), capim colônia (Panicum purpurascens), feijāo de porco (Canavalia ensiformes), milheto (Pennisetum americanum) e crotalária (Crotalaria juncea,), respectivamente. A braquiária apresentou maior produção de matéria seca $\left(9.696 \mathrm{~kg} \mathrm{ha}^{-1}\right)$, elevada relação $\mathrm{C} / \mathrm{N}(38,4)$, alto tempo de meia vida (86,5 dias) e grande persistência no campo. O feijão de porco apresentou alta produção de matéria seca $\left(8.950 \mathrm{~kg} \mathrm{ha}^{-1}\right)$, porém menor relação C/N $(17,4)$ e tempo de meia vida (39 dias), quando comparada as gramíneas. Por estas características, a braquiária e o feijão de porco são espécies com potencial utilização como plantas de cobertura no SPD no estado do Pará.

PALAVRAS-CHAVE: Tempo de meia vida, persistência de biomassa vegetal, reciclagem de nutrientes, relação C/N. 


\section{INTRODUCTION}

Sound agricultural practices requires environmental preservation and sustainable use of natural resources, the improvement of quality of agricultural soils, and reduction of production costs. No-tillage system is part of this context. The absent of periodic tillage allows reduction of working time and fuel consumption. In terms of soil quality, the maintenance of plant biomass over the soil promotes erosion control and soil moisture conservation. Besides increasing organic matter and enhancing soil biological activity (Topakci et al. 2011), no-tillage can reduce weed competition and improves the yield of rice (Oryza sativa) (Marenco et al. 1999).

In hot and humid regions with heavy rainfalls during the wet period, plant biomass maintenance on the soil surface is benefit, once those conditions accelerate residue decomposition (Timossi et al. 2007). Selection of plant species for use in notillage as cover crops depends on both their adaptation to the weather conditions of each region and grower interest (Silva and Rosolem 2008). In the Amazon, high humidity and temperature leads to an accelerated decomposition of organic matter. Thus, no-tillage consolidation in this region depends on several factors, including plant species capable of producing large amount biomass, long persistence of biomass in the soil and the storage of high nutrient amounts in the residues.

Legumes and grasses have distinct behavior in no-tillage treatments. Legume plant residues decompose rapidly due to their low $\mathrm{C} / \mathrm{N}$ ratio, as they have high nitrogen and watersoluble carbon contents (Aita et al. 2003). Legumes release great part of nutrients during the first 30 days after shoot deposition in the soil (Da Ros and Aita 1996). Grasses, on the other hand, are characterized by a high $\mathrm{C} / \mathrm{N}$ ratio in plant residues and longer persistence on the soil surface as a result of low decomposition rate. Hence, there is a minor amount of nutrient release, particularly N (Borkert et al. 2003). Species like signalgrass and pearl millet cultivated under notillage system increase the yield of the next soybean culture and its phosphorus content due to high biomass production and increased availability of soil P (Veronese et al. 2012). In the Cerrado region of Maranhão State, Brazil, signalgrass and pearl millet cultivated under no-tillage system increased $\mathrm{P}, \mathrm{K}, \mathrm{Ca}$, and $\mathrm{Mg}$ contents both in soil and organic matter (Bressan et al. 2013).

In the Amazon region, empirical and scientific attempts to implement and maintain no-tillage system with species previously used in other Brazilian regions have faced low production of crop residues and low quality of residues as the mains obstacles. Hence no-tillage systems success in the Amazon region depends entirely on the identification of cover crops with potential to produce great amount of lasting residues, and able to endure the high temperatures and humidity of this region. The objective of this study was to evaluate the potential of grasses and legumes as no-tillage crops, in the northeastern mesoregion of Pará, Brazil.

\section{MATERIALS AND METHODS}

The experiment was conducted in 2004, at the Farm School of Federal Rural University of Amazon (Ufra), located in Igarapé-Açú, Pará State (0107’33" S and 47³7’27” W, $39 \mathrm{~m}$ of altitude).

Regional climate is humid mesothermal, Ami type according to the Köppen classification, i.e., it is a rainy and humid tropical climate, with a short dry season, and mean temperature of $25^{\circ} \mathrm{C}$. Annual rainfall in 2004 (experimental period) was $2,500 \mathrm{~mm}$, with heavy concentration from January to June. Air relative humidity was around 85\% (Table 1). Maximum and minimum air temperatures were 32.2 and $21.4^{\circ} \mathrm{C}$, respectively (Embrapa 2007).

The soil of experimental area is classified as Ultisol (Embrapa 2013). Soil samples were collected from 0.0-0.2 $\mathrm{m}$ depth for chemical and physical analyses. All analyses were performed according to the methodology described by Embrapa (2009). The soil had a sandy-clayey texture in the A horizon, with $668 \mathrm{~g} \mathrm{~kg}^{-1}$ of sand, $141 \mathrm{~g} \mathrm{~kg}^{-1}$ of silt, and $191 \mathrm{~g}$ $\mathrm{kg}^{-1}$ of clay. Results from the chemical attributes were: $\mathrm{pH} 5.5$ (in water); organic matter, $14.9 \mathrm{~g} \mathrm{~kg}^{-1}$ soil; $\mathrm{P}, 10.2 \mathrm{mg} \mathrm{dm}^{-3} ; \mathrm{K}$, 0.05; Ca, 1.6; $\mathrm{Mg}, 1.2$; and base saturation, $45.3 \% \mathrm{cmol}_{\mathrm{c}} \mathrm{dm}^{-3}$.

The experimental design was arranged in randomized blocks, with five treatments: 1) legumes jack bean [Canavalia ensiformes (L.) DC], 2) sunn hemp (Crotalaria juncea L.), and grasses 3) dense crowngrass (Panicum purpurascens Mez.), 4) signalgrass (Brachiaria brizantha) (syn. Urochloa), 5) pearl millet (Pennisetum americanum L. Leeke). There were five replications, resulting in 25 plots. Each plot, of $25 \mathrm{~m}^{2}(2.5$ x $10 \mathrm{~m}$ ), was composed by six planting lines of $10 \mathrm{~m}$ length each, with $0.5 \mathrm{~m}$ spacing among lines and plants.

Species were first cultivated in 2003 on the same soil type, in a contiguous area. From the cultivated species, those that showed greatest potential for dry matter production (Teixeira et al. 2006) were used in this experiment. Seed sowing was manually made in July (period after harvest of

Table 1. Maximum and minimum temperatures and rainfall during the experimental period.

\begin{tabular}{lccc}
\hline Month & $\begin{array}{c}\text { Maximum } \\
\text { temperature }\left({ }^{\circ} \mathrm{C}\right)\end{array}$ & $\begin{array}{c}\text { Minimum } \\
\text { temperature }\left({ }^{\circ} \mathrm{C}\right)\end{array}$ & Rainfall $(\mathrm{mm})$ \\
\hline July & 31.7 & 21.8 & 228.6 \\
August & 31.9 & 21.8 & 443.4 \\
September & 32.4 & 21.7 & 476 \\
October & 33.2 & 21.6 & 50 \\
November & 33.7 & 21.4 & 11.2 \\
December & 33.7 & 22.6 & 79 \\
\hline
\end{tabular}


economic plant species), in holes, with the exception of dense crowngrass, which seeds were not viable so seedlings were used. Two legume and three grass plants were cultivated per hole, resulting in a stand of 80,000 and 120,000 plants per hectare, respectively. Fertilization was equally performed for all species, in the holes, with the application of $5 \mathrm{~g}$ NPK $10-$ 28-20 that corresponded to $400 \mathrm{~kg} \mathrm{ha}^{-1}$.

Harvest of the shoot part was carried out manually, cutting the plant at $0.05 \mathrm{~m}$ from the soil surface, after 105 days of growth, when plants were in initial flowering stage. Harvesting period was determined following cultivation of the same species performed in 2003, in same farm area. Harvested area of each plot was $2.0 \times 2.5 \mathrm{~m}$, where all biomass was spread on the soil surface.

To determine the amount of dry matter of cover crops in each plot, plant residues were collected from an inner plot area of $0.09 \mathrm{~m}^{2}$, using a 0.30 by $0.30 \mathrm{~m}$ square frame at two random locations (Stott et al. 1990). The collected material was dried in an oven with forced air circulation at $65^{\circ} \mathrm{C}$, until constant mass. Final values were transformed to ton per hectare, considering plant stand.

To determine time persistence of plant residue over the soil surface after biomass harvesting, percentage of soil coverage was measured on non-disturbed spread plant residue, in five different periods: on harvesting day and 21, 42, 63, and 84 days after shoot harvesting. The method used was "graded string" or linear transect, described by Hartwig and Laflen (1978) and Alves et al. (1998). On a nylon string, 50 points were marked with $6 \mathrm{~cm}$ spacing among them. At each evaluation time, the string was diagonally stretched at each plot so it provided two readings. Coverage percentage was measured according to the number of times that the string points were over the residue. Results from both readings were aggregated in order to obtain the coverage percentage value.

Description of residue decomposition and half-life time $\left(\mathrm{t}^{1 / 2}\right)$ was performed using the exponential mathematical model described by Thomas and Asakawa (1993), according to the equation $\mathrm{X}=\mathrm{X}^{0-\mathrm{kt}}$, where: $\mathrm{X}$ is the remaining dry matter amount in a t time, in days; $\mathrm{X}^{0}$ is the initial dry matter amount; and $\mathrm{k}$ is the decomposition constant. From the final $\mathrm{k}$ decomposition constant, $\mathrm{t}^{1 / 2}$ is calculated according to the equation $\mathrm{t}^{1 / 2}=\ln ^{2} / \mathrm{k}$.

To determine macronutrient content in plant tissues, plants were randomly collected, washed with distilled water, and placed in an oven with forced air circulation at $65^{\circ} \mathrm{C}$, until constant mass. Plant material was then ground in a Wiley grinder (sieve with a $0.33 \mathrm{~mm}$ mesh). Nitrogen was determined according to the Kjeldahl method; for other macronutrients, the nitropercloric digestion was applied; $\mathrm{P}$ was determined by colorimetry, $\mathrm{K}$ by flame photometry, $\mathrm{Ca}$ and $\mathrm{Mg}$ by atomic absorption spectrometry (Malavolta 2006).
Carbon content was assessed by a modified Walkley Black method (Tedesco et al. 1995).

Nutrient content was multiplied by the produced dry mass to obtain the accumulated macronutrient content. Dry mass results were submitted to analysis of variance and means were compared by the Duncan test $(\mathrm{p}<0.05)$. Regression analysis was performed for evaluation of residue persistence on soil surface.

\section{RESULTS}

Dry mass greatest production of aerial part (DMAP) was obtained by signalgrass $\left(9,696 \mathrm{~kg} \mathrm{ha}^{-1}\right)$ and jack bean $\left(8,950 \mathrm{~kg} \mathrm{ha}^{-1}\right)$, with no difference between them $(\mathrm{p}<0.05)$ (Figure 1). The other species had significantly lower dry mass production, their percentages in comparison with signalgrass were $41 \%$ for pearl millet, $51.6 \%$ for sunn hemp and $54 \%$ for dense crowngrass.

The species differ on residues soil coverage after biomass deposition. Signalgrass had the highest coverage level, reaching $100 \%$ at the harvesting day and $97 \%$ after 84 days of plant deposition on soil surface (Figure 2). After the $21^{\text {st }}$ day after harvesting, sunn hemp was the species with minor coverage (30\%) and, by the end of the experimental period, it reached only $15 \%$. Furthermore, it was the species that had the fastest decomposition rate. Although jack bean was one of the largest dry mass producers, it showed a high decomposition rate, as coverage ranged from $81 \%$ at the beginning of the evaluation (harvesting day) to $52 \%$ after 84 days, when the evaluation ended.

Contents of $\mathrm{C}$ in the DMAP, with the exception of dense crowngrass that had the lowest value, did not vary among species (Table 2). Still, legumes had higher $\mathrm{N}$ contents than grasses and, consequently, lower $\mathrm{C} / \mathrm{N}$ ratio.

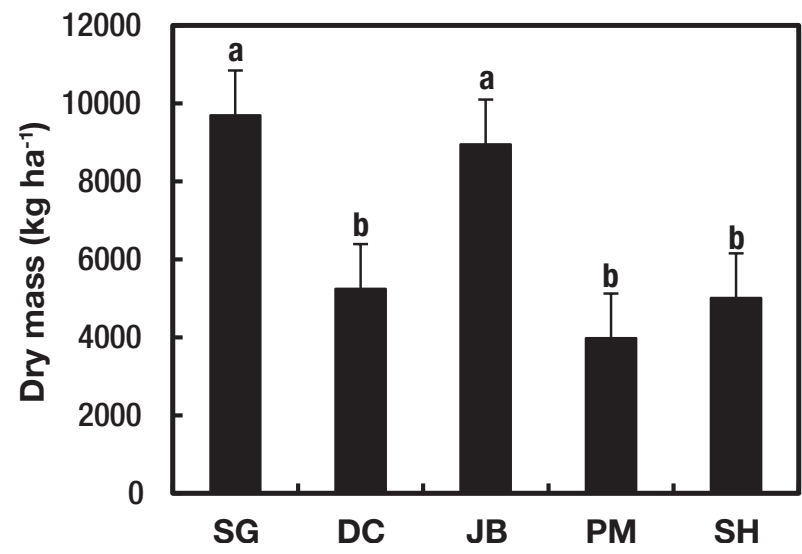

Figure 1. Production of dry mass of the aerial part (DMAP) of signalgrass (SG), dense crowngrass (DC), jack bean (JB), pearl millet (PM) and sunn hemp (SH). Letters represent differences by the Duncan test $(p<0.05)$. 
Table 2. Macronutrient contents and $\mathrm{C} / \mathrm{N}$ ratio in the dry mass of the aerial part of cover crops.

\begin{tabular}{|c|c|c|c|c|c|c|c|}
\hline \multirow{2}{*}{ Treatment } & C & $\mathrm{N}$ & $\mathrm{C} / \mathrm{N}$ & $P$ & K & $\mathrm{Ca}$ & $\mathrm{Mg}$ \\
\hline & \multicolumn{7}{|c|}{ 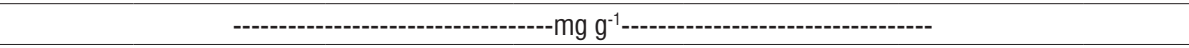 } \\
\hline Sunn hemp & $458 \mathrm{a}$ & $14.5 \mathrm{~b}$ & $31.5 \mathrm{c}$ & $2.1 \mathrm{c}$ & $28.1 \mathrm{bc}$ & $6.9 \mathrm{~b}$ & $3.2 \mathrm{c}$ \\
\hline Pearl millet & $456 \mathrm{a}$ & $11.5 \mathrm{c}$ & $40.5 b$ & $3.0 \mathrm{a}$ & $24.2 c$ & $2.6 \mathrm{c}$ & $3.9 \mathrm{~b}$ \\
\hline Jack bean & $447 \mathrm{a}$ & $25.9 \mathrm{a}$ & $17.4 \mathrm{~d}$ & $2.6 \mathrm{~b}$ & $24.3 \mathrm{c}$ & $10.9 \mathrm{a}$ & $3.2 \mathrm{c}$ \\
\hline Signalgrass & $439 a$ & $11.5 \mathrm{c}$ & $38.4 \mathrm{~b}$ & $2.1 \mathrm{c}$ & $31.5 a b$ & $2.8 \mathrm{c}$ & $6.5 \mathrm{a}$ \\
\hline Dense crowngrass & $400 \mathrm{~b}$ & $8.0 \mathrm{~d}$ & $51.3 \mathrm{a}$ & $1.7 \mathrm{~d}$ & $33.8 \mathrm{a}$ & $3.0 \mathrm{c}$ & $3.9 b$ \\
\hline CV (\%) & 6.3 & 11.2 & 12.4 & 12.2 & 9.8 & 18.8 & 11.5 \\
\hline
\end{tabular}

Means followed by the same letters in the columns do not differ from each other by the Duncan test $(p<0.05)$.

Table 3. Accumulated values of macronutrients in the dry mass of the aerial part of cover crops.

\begin{tabular}{lcccccc}
\hline \multirow{2}{*}{ Treatment } & $\mathrm{C}$ & $\mathrm{N}$ & $\mathrm{P}$ & $\mathrm{K}$ & $\mathrm{Ca}$ & $\mathrm{Mg}$ \\
\cline { 2 - 8 } & & & $-1.3 \mathrm{~b}$ & & \\
\hline Sunn hemp & $229.3 \mathrm{~b}$ & $7.3 \mathrm{c}$ & $1.1 \mathrm{~b}$ & $14.1 \mathrm{c}$ & $3.5 \mathrm{~b}$ & $1.6 \mathrm{c}$ \\
Pearl millet & $181.3 \mathrm{~b}$ & $4.6 \mathrm{c}$ & $1.2 \mathrm{~b}$ & $9.6 \mathrm{~d}$ & $1.0 \mathrm{~d}$ & $1.6 \mathrm{c}$ \\
Jack bean & $400.1 \mathrm{a}$ & $23.2 \mathrm{a}$ & $2.3 \mathrm{a}$ & $21.8 \mathrm{bc}$ & $9.8 \mathrm{a}$ & $2.9 \mathrm{~b}$ \\
Signalgrass & $425.7 \mathrm{a}$ & $11.2 \mathrm{~b}$ & $2.0 \mathrm{a}$ & $30.5 \mathrm{a}$ & $2.7 \mathrm{bc}$ & $6.3 \mathrm{a}$ \\
Dense crowngrass & $209.7 \mathrm{~b}$ & $4.2 \mathrm{c}$ & $0.9 \mathrm{~b}$ & $17.7 \mathrm{bc}$ & $1.8 \mathrm{~cd}$ & $2.0 \mathrm{c}$ \\
CV (\%) & 6.3 & 37.8 & 11.6 & 16.3 & 52.9 & 17.2 \\
\hline
\end{tabular}

Means followed by the same letters in the columns do not differ from each other by the Duncan test $(p<0.05)$.

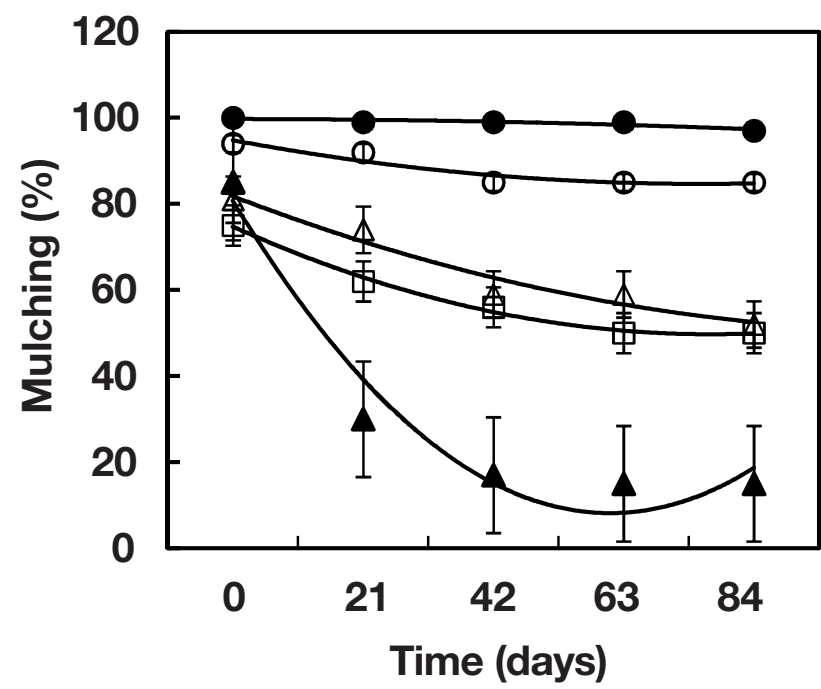

Figure 2. Soil coverage percentage of signalgrass $(\bullet)$, dense crowngrass $(\circ)$, jack bean $(\Delta)$, pearl millet $(\square)$ and sunn hemp $(\boldsymbol{\Delta})$ according to the time after havest.

ŷ $($ solid circle, $\bullet)=-0,1429 x^{2}+0,2571 x+99,6 R^{2}=0,81$ **

$\hat{y}\left(\right.$ circle, o) $=0,7857 x^{2}-7,2143 x+101,2 R^{2}=0,90^{* *}$

$\hat{y}$ (triangle, $\Delta)=1,0714 x^{2}-13,729 x+94,4 R^{2}=0,95$ **

$\hat{y}$ (square, $\square)=1,8571 x^{2}-17,343 x+90,2 R^{2}=0,99$ **

$\hat{y}$ (solid triangle, $\mathbf{\Delta}$ ) $=8,6429 x^{2}-67,357 x+139,4 R^{2}=0,95^{\star *}$

** Significant at $1 \%$ by the $\mathrm{F}$ test
Nutrient contents varied among species (Table 2). Jack bean showed higher $\mathrm{N}$ and $\mathrm{Ca}$ contents while pearl millet had higher $\mathrm{P}$ content. The higher K contents were observed in dense crowngrass and signalgrass, but this one did not differ from sunn hemp; the highest $\mathrm{Mg}$ contents were observed for signalgrass (Table 2).

Potential accumulation of nutrients into soil varied among species. Jack bean and signalgrass had the highest $\mathrm{C}$ and $\mathrm{P}$ accumulation capacity (Table 3). Furthermore, jack bean stood out for accumulating the highest amount of $\mathrm{N}$ and $\mathrm{Ca}$, while signalgrass was the species with greatest accumulation capacity of $\mathrm{K}$ and $\mathrm{Mg}$.

The dry matter decomposition constant (k) and half-life time showed longer persistence for grasses when compared with legumes; dense crowngrass obtained the highest halflife time (334 days) and sunn hemp, the lowest (30.7 days) (Table 4).

\section{DISCUSSION}

Signalgrass had high dry matter yield $\left(9,696 \mathrm{~kg} \mathrm{ha}^{-1}\right)$ (Figure 1), higher than the means found in a Cerrado area (Torres et al. 2005). The jack bean also showed high dry matter yield $\left(8,696 \mathrm{~kg} \mathrm{ha}^{-1}\right)$, due to its good adaptation in low fertility soils (Fernandes et al. 2007), like those found in Northeastern Pará. As a yield of $6 \mathrm{tha}^{-1}$ has been considered the minimum amount of plant residues for appropriate soil 
Table 4. Dry matter decomposition constant (k) and half-life time.

\begin{tabular}{lcc}
\hline Species & ${\mathrm{k}\left(\mathrm{g} \mathrm{g}^{-1}\right)}$ & Half-life time (days) \\
\hline Signalgrass & 0.00713 & $86.5 \mathrm{~b}$ \\
Dense crowngrass & 0.00208 & $334.0 \mathrm{a}$ \\
Pearl millet & 0.00756 & $91.7 \mathrm{~b}$ \\
Sunn hemp & 0.02258 & $30.7 \mathrm{c}$ \\
Jack bean & 0.00779 & $39.0 \mathrm{~b}$ \\
\hline
\end{tabular}

Means followed by the same letters in the columns do not differ from each other by the Duncan test $(p<0.05)$.

coverage in NT (Darolt 1998), the signalgrass and jack bean may be recommended as cover crops for that region.

Cultivated plants under weather conditions of Amazon have often different yields than those cultivated in the Cerrado. Jack bean showed a superior yield than that cultivated in the Cerrado $\left(3.43 \mathrm{t} \mathrm{ha}^{-1}\right)$. Moreover, pearl millet had better development under Cerrado conditions, producing $14.18 \mathrm{t}$ ha $^{-1}$ (Oliveira et al. 2002). The low dry matter production of legumes, including jack bean, may be related to the lack of fertilization and inoculation (Oliveira et al. 2002). For the same species, different yields between regions can reflect variation in soil properties and weather conditions, emphasizing the importance of regional studies for NT.

The lowest biomass decomposition of grasses, in comparison with legumes, may be explained by higher $\mathrm{C} / \mathrm{N}$ ratio (Table 2). Residue quality, especially $\mathrm{C} / \mathrm{N}$ ratio, is one of the factors that regulate decomposition and, therefore, persistence time of plant biomass in the soil (Borkert et al. 2003). Other factors that affect persistence of residues in the soil are the presence of (micro) organisms, soil chemical and physical characteristics, and environmental conditions (Swift et al. 1979).

The species produced plant biomass with low decomposition rate, mainly due to the overlap of cutting periods and periods of low rainfall, which was associated with high temperatures, when evapotranspiration is greater than precipitation; soil moisture was reduced during this period. According to Calegari et al. (1993), plant biomass persistence in the soil depends on soil moisture and temperature conditions. Higher signalgrass decomposition rates were found by Bernardes et al. (2010) in the Brazilian Cerrado, who described that, at 75 days, $33 \%$ of the dry mass had already been decomposed.

The lowest decomposition rate of signalgrass, dense crowngrass and pearl millet, in comparison with sunn hemp and jack bean may be related to their higher content of recalcitrant substances, such as cellulose and lignin that are present in tissue structures, once residue with higher $\mathrm{C} / \mathrm{N}$ ratios and less soluble molecules are more persistent in the soil (Barbosa et al. 2012). On the contrary, tissues with low $\mathrm{C} / \mathrm{N}$ ratio, more soluble $\mathrm{C}$ forms and high $\mathrm{N}$ contents have higher decomposition rate (Aita et al. 2003), as it occurs in legumes. Therefore, soil coverage species may be classified as of fast decomposition (legumes) and low decomposition (grasses).

Apart from legume characteristics (e.g. high $\mathrm{N}$ content, compared with grasses) that contribute to accelerate decomposition (Aita et al. 2003), the lower plant biomass quality produced by sunn hemp may have contributed to the increased decomposition rate (Kliemann et al. 2006), causing only $15 \%$ of soil coverage. Smaller fragments of dry matter promote more contact with the soil (Alvarenga et al. 2001), exposing larger contact surface to microbial attacks.

Dry mass carbon contents in the shoot part did not vary among cover crops, with the exception of dense crowngrass, which had the lowest value (Table 2). The highest accumulation, obtained by signalgrass and jack bean derived from their higher dry mass production (Table 2). Therefore, the carbon content does not determine the decomposition rate, although $\mathrm{N}$ content can influence $\mathrm{C} / \mathrm{N}$ ratio. This was the case of dense crowngrass that showed the lowest $\mathrm{N}$ content and highest $\mathrm{C} / \mathrm{N}$ ratio, thus leading to longer persistence in the soil. Torres et al. (2005) report lower $\mathrm{C}$ contents in sunn hemp, pearl millet, and signalgrass than those obtained in this study, due to higher soil fertility. High C accumulation in signalgrass and jack bean enabled greater input and, thereby, increased $\mathrm{C}$ stock in the soil.

Higher $\mathrm{N}$ content was associated with higher dry mass accumulation on aerial part of jack bean plants in comparison with other species (Tables 2 and 3), due, probably, to legume differentiated capacity to fix atmospheric nitrogen. Gama Rodrigues et al. (2007), when studying cover crops (grasses and legumes), observed that jack bean had the highest $\mathrm{N}$ contents and, consequently, lower $\mathrm{C} / \mathrm{N}$ ratio, resulting in better quality of residues. Nitrogen contents and accumulation observed in sunn hemp were similar to those obtained by Amabile et al. (1999). For jack bean, similar values were found by Fernandes et al. (2007). For sunn hemp, pearl millet and signalgrass Torres et al. (2005) related greater $\mathrm{N}$ contents to those noted in this study, mainly because of higher soil fertility, higher $\mathrm{pH}$ and organic matter contents.

Thus, low $\mathrm{N}$ contents and high $\mathrm{C} / \mathrm{N}$ ratio of studied grasses (Table 2) indicate lasting nutrient immobilization due to longer persistence of plant biomass in the soil. In these conditions, low release of $\mathrm{N}$ reduces its availability in the soil and thereby it inhibits microbial activity, reducing plant biomass decomposition (Gama-Rodrigues et al. 2007). Therefore, $\mathrm{N}$ availability to plants decreased, forcing nutrient application in soil in order to favor the following crop yield. 
The lower $\mathrm{C} / \mathrm{N}$ ratio of legumes is due to high $\mathrm{N}$ contents (Table 2). Lower $\mathrm{C} / \mathrm{N}$ ratios than those obtained in the current study for sunn hemp, pearl millet, and signalgrass were observed by Torres et al. (2005) under Cerrado conditions. The superior values may be related to weather conditions, i.e., temperature, humidity and luminosity, which are higher in the North region of Brazil, promoting greater efficiency of $\mathrm{CO}_{2}$ fixation and resulting in synthesis of compounds with higher $\mathrm{C} / \mathrm{N}$ ratio.

The $\mathrm{P}$ content in jack bean tissues was superior to those obtained in other studies (Fernandes et al. 2007; Oliveira et al. 2002). Apart from soil factors, weather and climatic variation during the year may influence nutrient uptake by plants. This was obvious for Amabile et al. (1999), who found different $P$ contents in sunn hemp according to its cultivation in different times of the year.

Accumulation of $\mathrm{P}$ was also higher in jack bean because of high organic matter content and production (Table 3). Oliveira et al. (2002), working with same species, observed less amounts of $\mathrm{P}$ than those found in the current study due to minor dry matter content and production. Conversely, Fernandes et al. (2005) obtained higher amounts of P. Regarding sunn hemp, Silva et al. (2006) found larger P quantities than this study, as a result of higher dry matter production.

The highest $\mathrm{K}$ contents in shoot dry mass of signalgrass and dense crowngrass (Table 2) are related to the minor CEC found in the roots of those plants, in comparison with legumes (Marschner 2012). This confirms the high K recycling capacity of grasses and their potential use as cover crops (Raij et al. 1997). Lower K contents and accumulation in signalgrass were obtained by Primavesi et al. (2006).

Jack bean and pearl millet showed the lowest $\mathrm{K}$ contents (Table 2); however, due to great dry matter production, jack bean had higher accumulated values of $\mathrm{K}$ than sunn hemp and pearl millet, differing from values described in the literature. Contents found in this study are higher than those observed by Oliveira et al. (2002) and Ceretta et al. (1994).

Sunn hemp K contents were higher than those described by Amabile et al. (1999) and Silva et al. (2006); however, due to its low dry matter production, $\mathrm{K}$ accumulation was lower than what was found by those same authors.

Jack bean was the cover crop species that showed highest Ca content and accumulation in aerial part dry mass (shoot), followed by sunn hemp (Tables 2 and 3). This suggests that legumes, when compared with grasses, absorb and incorporate in their tissues, a greater $\mathrm{Ca}$ amount from soil. This occurs because legumes have a higher root capacity for cation exchange, promoting greater affinity with divalent cations (Marschner 2012).
High half-life time (Table 4) may be explained by low rainfall during the time plant biomass remained on the soil surface, from October to December (Table 1), directly affecting its decomposition. Costa et al. (2005) studied nutrient decomposition and nutrient release by tree litter in a Eucalyptus grandis stand and concluded that there was higher decomposition rate during the wettest rainfall period. Appropriate conditions of soil moisture and temperature increase microbial activity and enhance decomposition rate (Alves et al. 2006).

Cover crops with different chemical composition have been cultivated in order to adjust nutrient kinetics release for crop uptake (Aita and Giacomini 2003). Such process has resulted in faster decomposition of more recalcitrant materials and slower decomposition of better quality materials (Gama-Rodrigues et al. 2003). Therefore, signalgrass-jack bean intercropped as cover crops, may be a viable alternative for no-tillage system in Northeastern Pará, once signalgrass have high dry matter production and low decomposition rate, and jack bean high dry matter production and high decomposition rate.

High accumulation of $\mathrm{N}, \mathrm{P}$, and $\mathrm{Ca}$, and low $\mathrm{C} / \mathrm{N}$ ratio, as found in jack bean are desirable characteristics of plants that produce good quality residue (Gama Rodrigues et al. 2007). Thus, this species may be a cover crop alternative in regions with high rainfall and temperatures, and soils of low fertility. On the other hand, signalgrass showed high accumulation of $\mathrm{C}, \mathrm{K}$, and $\mathrm{Mg}$, and was the greatest dry matter producer, also becoming an alternative for NT.

\section{CONCLUSIONS}

Signalgrass had greater dry mass production and was the species that incorporated the highest amount of $\mathrm{C}, \mathrm{K}$, and $\mathrm{Mg}$. Jack bean also showed high biomass production and was the species that most incorporated N, P, and Ca. Signalgrass and jack bean are species that show potential to be used as cover crops due to their biomass production, above $6 \mathrm{tha}^{-1}$. Their residues provide appropriate soil coverage and contribute for recycling large amounts of nutrients.

\section{ACKNOWLEDGMENT}

To Conselho Nacional de Desenvolvimento Cientifico e Tecnológico (CNPq), grant number 479524/2007-6.

\section{REFERENCES}

Aita, C.; Giacomini, S.J. 2003. Decomposição e liberação de nitrogênio de resíduos culturais de plantas de cobertura de solo solteiras e consorciadas. Revista Brasileira de Ciência do Solo, 27: 601-612. 
Alvarenga, R. C.; Cabezas, W. A. L.; Cruz, J. C.; Santana, D. P. 2001. Plantas de cobertura de solo para sistema plantio direto. Informe Agropecuário, 22: 25-36.

Alves, A.G.C.; Cogo, N.P.; Levien, R. 1998. Comparação entre os métodos da transeção linear e fotográfico na avaliação de cobertura vegetal morta, sob dois métodos de preparo, após a colheita da soja. Revista Brasileira de Ciência do Solo, 22: 491-496.

Alves, A.R.; Souto, J.S.; Santos, R.V.; Campos, M.C.C. 2006. Decomposição de resíduos florestais de espécies da caatinga, na região de Patos, PB. Revista Brasileira de Ciências Agrárias, 1: $57-63$.

Amabile, R.F.; Francelli, A. L.; Carvalho, A.M. 1999. Absorção de $\mathrm{N}, \mathrm{P}, \mathrm{K}$ por espécies de adubos verdes cultivados em diferentes épocas e densidades num latossolo vermelho-escuro argiloso sob cerrados. Revista Brasileira de Ciência do Solo, 23: 837-845.

Barbosa, T.; Arcângelo, M. L.; Pereira, M. P.; Pimentel, C. 2012. Decomposição e ciclagem de nutrientes dos resíduos de quatro plantas de cobertura do solo. Idesia, 30: 55-64.

Bernardes, T.G.; Silveira, P. M.; Mesquita, M. A. M.; Aguiar, R.A.; Mesquita, G. M. 2010. Decomposição e liberação de nutrientes dos capins braquiária e Mombaça, em condições de Cerrado. Pesquisa Agropécuaria Tropical, 40: 370-377.

Borkert, C.M.; Gaudêncio, C.A.; Pereira, J.E. 2003. Nutrientes minerais na biomassa da parte aérea em culturas de cobertura do solo. Pesquisa Agropecuária Brasileira, 38: 143-153.

Bressan, S.B.; Nóbrega, J.C.A.; Rafaela S. A. Nóbrega, R.S.A.; Barbosa, R.S.; Sousa, L.B. 2013. Plantas de cobertura e qualidade química de Latossolo Amarelo sob plantio direto no cerrado maranhense. Revista Brasileira de Engenharia Agricola e Ambiental, 17: 371-378.

Calegari, A.; Mondarno, A.; Bulisani, E.A.; Costa, M.B.B. da; Miyasaka, S.; Amado, T.J.C. 1993. Adubação verde no sul do Brasil. 2. ed. Rio de Janeiro: Assessoria e Serviços a Projetos em Agricultura Alternativa, p. 1-56.

Ceretta, C.A.; Aita, C.; Braida, J.A.; Pavinato, A.; Salet, R.L. 1994. Fornecimento de nitrogênio por leguminosas na primavera para o milho em sucessão nos sistemas de cultivo mínimo e convencional. Revista Brasileira de Ciência do Solo, 18: 215-220.

Costa, G.S.; Gama-Rodrigues, A.C.; Cunha, G.M. 2005. Decomposisão e liberação de nutrientes da serapilheira foliar em povoamento de Eucalyptus grandis no norte fluminense. Revista Arvore, 29: 563-570.

Da Ros, C.O.; Aita, C. 1996. Efeito de espécies de inverno na cobertura do solo e fornecimento de nitrogênio ao milho em plantio direto. Revista Brasileira de Ciências do Solo, 20: 135-140.

Darolt, M.R. 1998. Princípios para implantação e manutenção do sistema. In: Darolt, M. R. Plantio direto: Pequena propriedade sustentável. Iapar, Londrina, Paraná, p.16-45.

Duda, G. P.; Guerra, J.G.M.; Monteiro, M.T; De-PollI, H.; Teixeira, M.G. 2003. Perennial herbaceous legumes as live soil mulches and their effects on $\mathrm{C}, \mathrm{N}$ and $\mathrm{P}$ of the microbial biomass. Scientia Agricola, 60: 139-147.
EMBRAPA, Empresa Brasileira de Pesquisa Agropecuária. 2007. Boletim agrometeorológico 2006 - Igarapé-Açu. 1a ed. Embrapa Amazônia Oriental, Belém, Pará, 2007, 30 p.

EMBRAPA, Empresa Brasileira de Pesquisa Agropecuária. 2009. Manual de análises químicas de solos, plantas e fertilizantes. $2 \mathrm{da}$ ed. Embrapa, Brasília, Distrito Federal, 2009, 627p.

EMBRAPA, Empresa Brasileira de Pesquisa Agropecuária, Centro Nacional de Pesquisa de Solos. 2013. Sistema Brasileiro de Classificação de Solos. 2da ed. Embrapa, Rio de Janeiro, 2013, 412p.

Fernandes, A. R.; Morais, F. O.; Linhares, L. C. F.; Silva, G. R. 2007. Produçáo de matéria seca e eficiência nutricional para $\mathrm{P}, \mathrm{Ca}$ e Mg em leguminosas herbáceas. Acta Amazonica, 37: 169-176.

Gama-Rodrigues, A.C.; Barros, N.F.; Santos, M.R. 2003. Decomposição e liberação de nutrientes do folhedo de espécies florestais nativas em plantios puros e mistos no sudeste da Bahia, Brasil. Revista Brasileira de Ciência do Solo, 27: 1021-1031.

Gama-Rodrigues, A.C.; Gama-Rodrigues, E.F.; Brito, E.C. 2007. Decomposição e liberação de nutrientes de resíduos culturais de plantas de cobertura em Argissolo Vermelho-Amarelo na região Noroeste Fluminense-RJ. Revista Brasileira de Ciência do Solo, 31: 1421-1428.

Hartwig, R.O.; Laflen, J.M. 1978. A meters tick method for measuring crop residue cover. Journal of Soil and Water Conservation, 33: 90-91.

Kliemann, K.J.; Braz, A.J.P.B.; Silveira, P.M. 2006. Taxas de decomposição de resíduos de espécies de Cobertura em latossolo vermelho distroférrico. Pesquisa Agropecuária Tropical, 36: 21-28.

Malavolta, E. 2006. Manual de nutrição mineral de plantas. São Paulo: Editora Agronômica Ceres Ltda., 638p.

Marschner, P. 2012. Mineral Nutrition of Higher Plants. $3^{\text {rd }}$ ed. New York, Academic Press/ Elsevier, USA, 651p.

Marenco, R.A.; Santos, A. M. B. 1999. A rotação de cultura reduz a mato competição e aumenta o teor de clorofila e a produtividade do arroz. Pesquisa Agropecúaria Brasileira, 34: 1881-1887.

Oliveira, T.K.; Carvalho, G.J.C.; Moraes, R.N.S. 2002. Plantas de cobertura e seus efeitos sobre o feijoeiro em plantio direto. Pesquisa Agropecuária Brasileira, 37: 1079-1087.

Primavesi, A.C.; Primavesi, O.; Correa, L.A.; Silva, A.G.; Cantarella, H. 2006. Nutrientes na fitomassa de capim - marandu em função de fontes e doses de nitrogênio. Ciência Agrotecnologia, 30: $562-568$.

Raij, B. V.; Cantarella, H.; Quaggio, A.J.; Abreu, C.A. 1997. Interpretação de resultados e análises de solo. In: Raij, B.V.; Cantarella, H.; Quaggio, A.J.; Furlani, A.M.C. Recomendaçôes de adubação e calagem para o estado de São Paulo. Instituto Agronômico de Campinas, Campinas, São Paulo, p.08- 13.

Silva, E.C. da. Muraoka, T. Buzeti, S. Veloso, M.E.C. Trivelin, P.C.O. 2006. Aproveitamento do nitrogênio $(15 \mathrm{~N})$ da crotálaria e do milheto pelo milho sob sob plantio direto em Latossolo Vermelho de Cerrado. Ciência Rural, 36: 739-746.

Silva, H.R.; Rosolem, C.A. 2008. Crescimento radicular de espécies utilizadas como cobertura decorrente da compactaçáo do solo. Revista Brasileira de Ciência do Solo, 32: 1399-1407. 
Stoot, D.E.; Stroo, H.F.; Elliot, L.F.; Papendick, R.J.; Unger, P.W. 1990. Wheat residue loss from fields under no-till management. Soil science society of America journal, 54: 92-98.

Swift, M.J.; Heal, O.W.; Anderson, J.M. 1979. Decomposition in terrestrial ecosystems. Blackwell Scientific Publication, Oxford, 1979. 384p.

Tedesco, M.J.; Gianelo, C.; Bissani, C.A.; Bohnen, H.; Volkweiss, S.J. 1995. Análise do solo, plantas e outros materiais. Universidade Federal do Rio Grande do Sul, Porto Alegre, 1995, 174 p.

Teixeira, P.E.G.; Soares, T.G.; Sampaio, L.S. 2006. Avaliação de espécies vegetais como produtoras de palha para plantio direto no nordeste paraense. Revista de Ciências Agrárias, 45: 23-35.

Timossi, P.C.; Durigan, J.C.; Leite, G.J. 2007. Formação de biomassa vegetal por braquiárias para a adoção do sistema de plantio direto. Bragantia, 66: 617-622.
Thomas, R. J.; Asakawa, N. M. 1993. Decomposition of leaf litter from tropical forage grasses and legumes. Soil Biology and Biochemistry, 25: 1351-1361.

Topakci, M.; Karayel, D.; Canakci, M.; Furat, B.; Uzun, B. 2011. Sesame hill dropping performance of a vacuum seeder for different tillage practices. Applied Engineering in Agriculture, 27: 203-209.

Torres, J.R.; Pereira, M.G.; Andriolli, I.; Polidoro, J.C.; Fabian, A.J. 2005. Decomposição e liberação de nitrogênio de resíduos culturais de plantas de cobertura em um solo de cerrado. Revista Brasileira de Ciências do Solo, 29: 609-618.

Veronese, M.; Francisco, E.A.B.; Zancanaro, L.; Rosolem, C.A. 2012. Plantas de cobertura e calagem na implantaçáo do sistema plantio direto. Pesquisa Agropecuária Brasileira, 47: 1158-1165.

Recebido em 07/11/2013

Aceito em 17/03/2014 